\title{
Child's Place in Nature: Talking Animals in Victorian Children's Fiction
}

Stories in which animals talk are a very ancient genre, or group of genres, dating back to Aesop or beyond. They can be used to teach a moral, to satirize humanity, to allegorise spiritual or political messages, to invert hierarchies in a carnivalesque mode. ${ }^{1}$ These stories were not, initially, directed especially at children, and still need not be so: a twentieth-century example would be Orwell's Animal Farm, a book which caused me great distress when I read it as a child, thinking it was a children's book. (Though this anecdote contains all sorts of assumptions about what children should read, what children are, and how they are different from adults.) Margaret Blount maintains that children often do not like animal stories, but adults like giving them to children, because 'they are supposed to be "improving" in some way, pointing oblique and therefore palatable morals, or helping one's nature study along'. ${ }^{2}$ Another explanation would be that, like fairy tales, this is an adult genre that has drifted down to children's literature, as the boundaries of what is childish and what is adult have been redefined.

A separate children's literature is a relatively recent development, beginning in the Eighteenth Century. Claims that childhood itself is a modern invention, unknown in classical or medieval times, have recently been much disputed by historians, but a particular Romantic construction of childhood was being formed in the late Eighteenth and early Nineteenth Centuries. ${ }^{3}$ If the child is seen as nearer to Nature than the adult, nature stories must be specially suitable for childish readers; if the child is more imaginative than the adult, the fantasy element (we all know animals don't talk) is also more suitable to children. Notice that these definitions of the child carry along with

1 See Margery Blount, Animal Land: The Creatures of Children's Fiction, London: Hutchinson, 1974.

2 ibid. p. 16.

3 Gillian Avery, Childhood's Pattern: A study of the heroes and heroines of children's fiction, 1770-1950, London: Hodder and Stoughton,1975; Hugh Cunningham, Children and Childhood in Western Society Since 1500, London: Longman, 1995. 
them (or even proceed from) complementary implied definitions of the adult, in the same way that femininity is defined by taken-for-granted assumptions about masculinity. So the adult becomes a person who is divorced from Nature, rational, logical, scientific. This is also an adult who knows what the differences are between animals and humans, how our species is defined. The child, by contrast, has still to learn these markers and rules, and exists in a space of play in which boundaries could potentially be transgressed. There is also the seemingly transhistorical fact that children are born unable to speak, and in this respect are like animals - though in a culture which believed animals could speak, this would not be a similarity, and tales about talking animals would not be seen as 'fantasy'. Here I am suggesting also that what exactly we think about animals, how we define them, contains other important sets of assumptions that serve to construct the animal/human divide.

I am beginning here to touch on some issues that were of course central and worrying to many Victorians. The title of my paper, 'Child's Place in Nature', is an adaptation, or parody, of T.H. Huxley's Man's Place in Nature, published in 1863, in which he argues for the evolutionary kinship of men and 'the man-like apes'. ${ }^{4}$ Huxley's book was part of a wider controversy on the nature of the human in relation to the animal, brought on by the publication of Darwin's Origin of Species. The purpose of my paper is to trace how, in the Nineteenth Century, scientific debate about the human and the animal intersects with, or leaves its mark on, the venerable genre of the animal story, in its contemporary child-directed form. What kind of child is being constructed in these works to hear what kind of message about Nature? More specifically, how is the issue of animal speech handled, at a time when the possession of language became a vital sign of the difference between men and animals - either a difference to be insisted upon, or one to be explained away? In dealing with these issues, what does children's literature make possible that is not allowed in writing directed at adults?

For the purposes of this paper, I am going to concentrate on Mrs. Gatty's Parables from Nature (1855-71) and Kipling's Jungle Books (1894-5), with some

\footnotetext{
4 London: Williams and Norgate, 1863.
} 
reference to Kingsley's The Water Babies (1863)..$^{5} \mathrm{I}$ am not interested, at the moment, in those writers who, like Lewis Carroll or Hilaire Belloc, obviously parody the animal story genre in children's literature. I want instead to look at writers who convey some kind of scientific or rationalist allegiance - who, as well as using their talking animals to teach morality and to delight by their obvious fictionality, also claim to be conveying facts and truths about Nature, 'helping our nature study along', as Blount puts it. In his story 'Tiger, Tiger', from the first Jungle Book, Kipling draws attention to the newness, the modernity, of his animal stories as opposed to the old, superstitious kind. Mowgli, brought up in the Jungle by wolves, has returned to the human village, and he listens to old Buldeo, the village hunter, telling 'wonderful' stories 'of the ways of beasts in the Jungle'. Mowgli, who 'knew something about what they were talking of, had to cover his face not to show that he was laughing'. Buldeo explains that the tiger known by Mowgli as Shere Khan 'was inhabited by the ghost of a wicked old money-lender', who limped, and this is why the tiger limps. Mowgli intervenes to pour scorn on this superstition: 'Are all these tales such cobwebs and moontalk? ... That tiger limps because he was born lame, as everyone knows. To talk of the soul of a money-lender in a beast that never had the courage of a jackal is child's talk' (I:76-7).

The use of 'child' as a term of abuse here is interesting, associating it with fantasy and mythmaking. In contrast, Kipling is implicitly claiming that his stories about Mowgli and the Jungle are 'grown-up', demystified, accurate. And yet of course they are not - grown-ups know animals can't talk, as they do to Mowgli. It is only in a child's perception that this can happen - in stories addressed to children, from the point of view of the child Mowgli. In the only Mowgli story addressed to adults, 'In the Rukh', the animals don't talk; and those of Kipling's other adult tales which include

5 Mrs. Gatty, Parables from Nature, London: J. M. Dent and Co., 1907; Rudyard Kipling, The Jungle Book, Harmondsworth: Puffin, 1994; The Second Jungle Book, London: Macmillan, 1962; Charles Kingsley, The Water Babies, 1912?. Subsequent page references to these editions will be in brackets in the text. The two Jungle Books will be distinguished as I and II. 
talking animals are much more obviously only jokey political allegories. ${ }^{6}$ In the Jungle

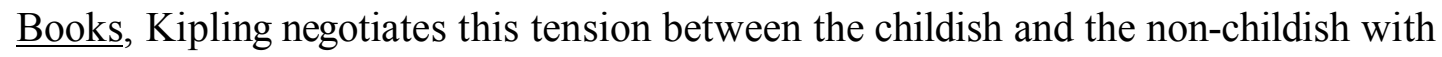
considerable skill. This tension is central to much children's literature: on the one hand, children are being instructed in adult truth, to help them grow up; on the other, the child's special, separate world is being celebrated. ${ }^{7}$

Mrs Gatty also shows the need to refer to an adult, scientific truth which opposes her fictionalising, mythologising tendencies. In a parable about 'Night and Day', she playfully allows that 'now the wise men will not allow that Night and Day drive round the world in cars with horses to them. Well, perhaps they don't. Perhaps it is really true that the earth is a dark ball, hanging in the open space which we call the firmament of heaven, moving slowly round the shining sun, but spinning like a top all the time itself, so that first one side and then the other faces the brightness; and thus there is a constant change from lightness to darkness and darkness to light going on all over the world' (246). The length and carefulness with which this theory is described works against the dismissiveness of 'perhaps'. Nevertheless, Mrs Gatty asserts, Night and Day still praise the Lord, and we may hear their voices in a new scientific and technological context: 'as musical sounds . . . sweep along the wires of the electric telegraph on breezy days' (247). An important point that emerges about Mrs Gatty here is that she, like Kingsley, and like many early Victorian scientists, is pursuing science in a religious context, and sees this as no contradiction. Both of them give the highest authority in their children's books to the naturalist with the microscope. He represents a true science of observation and religious wonder; but both writers also create figures who represent an illegitimate, atheistic, materialistic, false science given

6 'In the Rukh' is in Many Inventions, London: Macmillan, 1893, pp. 189-225; see also 'A Walking Delegate', in The Days Work, London: Macmillan 1898, pp. 45-72, and 'Below the Mill Dam', in Traffics and Discoveries, London: Macmillan, 1904, pp. 369-393.

7 For an interesting discussion of this tension in Victorian children's literature, see U.

C. Knoepflmacher, 'The Balancing of Child and Adult: An Approach to Victorian Fantasies for Children', Nineteenth Century Literature, 37: 4 (March 1983): 497-530. 
to unproven speculation and categorical assertion. Both Mrs Gatty and Kingsley were talented naturalists themselves - in the Victorian context, the implication of calling them 'amateur' scientists would be misleading. Darwin too was a gentleman 'amateur', as opposed to the new aggressive professionals, Tyndall and Huxley.

As children's writers then, both Mrs Gatty and Kingsley present 'facts' of natural history, combined with messages of Christian faith and morality, and 'childish' fantasy. This mixture is negotiated by Kingsley through an exuberant, carnivalesque mode. His allusions to the 'truth' or otherwise of his fictions are tied up in a complicated double-bluff: 'Am I in earnest? Oh, dear no! Don't you know that this is a fairy-tale, and all fun and pretence; and that you are not to believe one word of it, even if it is true?' (57). Mrs Gatty's parables, on the other hand, are more single minded, but often seem to be getting out of control, as the morals she tries to attach to her material don't quite fit.

Before embarking on a more detailed analysis of my children's writers, I want to look briefly at the construction of the child by Victorian science, in relation to language and to animals. In 1877, the journal Mind contained a translation of an article, first published in 1876, by Hypolite Taine, on 'The Acquisition of Language by Children'. In the next number, there followed an article by Darwin, 'Biographical Sketch of an Infant', corroborating much of what Taine had said, though, typically of Darwin, without formulating as many conclusions. ${ }^{8}$ Taine both compares the child's language to animal noises, and differentiates it from them: 'she takes delight in twitter like a bird', but 'if I compare her to animals ... I find that . . she far surpasses them in the delicacy and adundance of her expressive intonations.' Nevertheless, the child's speech is given a natural origin - for instance, her word 'Ham' for 'eat' is described as 'the natural vocal gesture of a person snapping up anything'(252, 257). Darwin's article rather differently also suggests a natural origin for language - the musical intonations of the child support the theory he elaborates in The Expression of the

8 Mind 2: 6 (1877): 252-9; 2: 7 (1877): 285-94. Subsequent page references to these articles are in brackets in the text. 
Emotions in Man and Animals (1874), 'that before man uttered articulate language, he uttered notes in a true musical scale as does the anthropoid ape Hylobates' (293).

As well as comparing the child to animals, both Darwin and Taine compare her (or him, in Darwin's case) to primitive peoples. For Taine, 'the mental state of a child' is in many respects 'that of primitive peoples at the poetical and mythological stage' (258). For Darwin, less positively, the child's fears may be 'the inherited effect of real dangers and abject superstitions during ancient savage times' (288). This connection is put in a larger framework by Taine, using one of the staples of Victorian evolutionary thinking - recapitulation theory: 'the child presents in a passing state the natural characteristics that are found in a fixed state in primitive civilisations, very much as the human embryo presents in a passing state the physical characteristics that are found in a fixed state in the classes of inferior animals' (259). Ontogeny recapitulates phylogeny here - that is, the development of each individual parallels and is causally connected to, the development of the race as a whole. ${ }^{9}$ There are many unexamined assumptions in recapitulation theory, and we can see some illogicalities in Taine's application of it: if 'the child' recapitulates in a 'passing state' the 'fixed state' of adults in so-called 'primitive civilisations', where does that put the 'primitive' child?

We can see in Taine's article the Romantic child being reconstituted as the evolutionary child, more primitive and more poetic, literally closer to animals, than adults. While the child appears then almost as a 'missing link' between animal and human, primitive and civilised, at the same time a hierarchy is assumed, inferior/superior animals, primitive/civilised man. Interestingly, in a passing analogy, Taine also gives this hierarchy a class dimension: man's language and ideas are distinguished from animals' by their 'delicacy', 'he is among them what a great and fine poet, Heine or Shakespeare, would be among workmen and peasants' (253). Mrs Gatty, Kingsley and Kipling all at some point read class meanings into, or out of, animal/human or animal/animal hierarchies. For instance, Mrs Gatty draws this moral

\footnotetext{
${ }^{9}$ For the origins of and problems with recapitulation theory, see William Coleman, Biology in the Nineteenth Century: Problems of Form, Function, and Transformation, London: John Wiley and Sons, 1971, pp. 36, 47-54, 56, 80, 82.
} 
from her story 'Kicking', which is about a rebellious colt who has to be tamed:

'Animals under man - servants under masters - children under parents - wives under husbands - nations under rulers - all under God' (268). Here gender, 'wives under husbands', is added to the list of hierarchies. Mrs Gatty is, however, no evolutionist evolution adds a time-dimension to this already given hierarchy. What the addition of this dimension blurs is the question of who can change into what in the hierarchy: children, obviously, change into adults; in the colonialist project, primitive peoples can be changed into civilised peoples, or they can be eliminated as relics belonging to an earlier time; but what about animals? Some have changed into men: are the rest bound for extinction, or do they remain as living fossils? Even more problematic, what about the lower classes? Do they evolve?

Kingsley, in The Water Babies suggests this is so, by turning Tom the working class chimney sweep into a water-baby with gills, who has to live through a time with the 'lower' animals till he can emerge as a morally responsible, middle-class adult human. As the Queen of the fairies says, 'He is but a savage now, and like the beasts which perish: and from the beasts which perish he must learn' (42). ${ }^{10}$ Tom, the fishlike water baby, is like one of the early stages of the human embryo, embryology, via recapitulation theory, providing one of the key arguments for evolution. Mrs Gatty, as opposed to Kingsley, does not use an evolutionary model, and being content with one's station in life is the moral of many of her stories. Class analogies do, however, create confusion in her stories. She is very fond of the analogy of metamorphosis - the caterpillar changing into the butterfly. She uses it not as an analogy of evolution, but, as was standard among Victorian writers and painters, as an analogy of the soul's immortality, our translation after death into a higher and different spiritual world. But in her story 'A Lesson of Faith ', the caterpillar is given a humble, worthy workingclass character, while the butterfly is frivolous, stupid and upper-class (1-6). Why the caterpillar should be so pleased to find out it will become a butterfly is thus unclear,

10 See also Harriet Ritvo, The Animal Estate: The English and Other Creatures in the Victorian Age, Harmondsworth: Penguin, 1987, p. 16, for the analogy between the 'lower' classes and the 'lower' animals. 
as is the politics of the implied change in class terms. The parable has escaped from its moral.

What I'm arguing is that all the parts of this multiple hierarchy don't always work smoothly together. While all the writers I am concerned with are keen to assert hierarchy, all to some extent also undermine it, suggesting in particular that animals may be better than humans, and children than adults. There are also tensions in Taine's formulations of the idea. In comparing man to a highly civilised, educated, refined, grown-up 'poet', Taine contradicts his later assertion that the child is nearer to the 'poetical and mythological stage' of primitive peoples. There is a profound ambivalence as to how the 'lower' stages of the hierarchy are to be valued. This 'poetic' propensity in the child is applied by Taine specifically to the phenomenon of talking animal stories, in a passage which I want to quote at length, as it has many interesting analogies with the children's literature I am focusing on:

If we speak to her of an object... her first question always is - 'What does it say?' - 'What does the rabbit say? - 'What does the bird say?' - 'What does the horse say?' - 'What does the big tree say?' Animal or tree, she immediately meets it as a person and wants to know its thoughts and words; that is what she cares about; by a spontaneous induction she imagines it like herself, like us; she humanises it. This disposition is found among primitive peoples, the more strong the more primitive they are; in the Edda, especially in the Mabinogion, animals have also the gift of speech. (258)

We have already seen the propensity of 'primitive' people to tell 'childish' stories about animals disparaged by Kipling - his attitude to primitive people in this story seems more like Darwin's to the 'abject superstitions' of savages. The passage from Taine implies that perhaps the child can reclaim as fiction what the adult has to lose as primitive superstition, but Mrs Gatty, Kingsley and Kipling all accompany such a move with careful re-writings, re-formulations and framings of the old 'primitive' traditions. This is most evident in Mrs Gatty's story, 'Inferior Animals', which uncannily echoes Taine's words, though it was published before his article. In Taine, the child asks "'What does it say?" - "What does the rabbit say?" - "What does the bird say?"' etc. Mrs Gatty's story opens like this: 'What do they say? - What do 
they say? - Whay do they say? - What can they have to say, those noisy, cawing rooks?' (193) As in Taine, the innate assumption that animals talk is attributed to children: 'See the little child as she babbles to her cat on the rug, and would fain be friends' (194). This story is the only one of her parables in which Mrs Gatty ruminates about actual animal speech, and the differences of human and animal in regard to language. In other parables, she cheerfully attributes speech not just to animals, but to trees, flowers and inanimate objects, making it clear by this undiscriminating attitude that the speech is only an arbitrary imaginative device. 'Inferior Animals' is also the only story in which she tackles evolutionary thought, by means of a comic parody: the rooks turn out to be arguing, from available evidence, that man is really a degenerate form of rook. It is as if evolutionary thought raises too uncomfortably the idea of animal/human kinship, and causes her to examine what she is doing in using the talking animal convention.

Mrs Gatty, as I have said, was no Darwinian, and subscribes rather to Paleyan Natural Theology, a set of ideas highly influential on Victorian science. ${ }^{11}$ Natural theologians argue that the natural world contains evidence of the existence and goodness of God, and this is the justification for nature study. But, perhaps because she is writing for children, Mrs Gatty feels no need to argue this position closely or consistently. I have already pointed to the arbitrary nature of her proceedings, and in the parable 'Motes in the Sunbeam' two different religious interpretations are given, by a character in the story, to the same phenomenon (133-7). This story seems to admit that morals drawn from nature are just analogies, not evidence, as does her title,

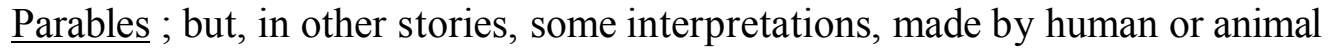
characters, are clearly labelled as wrong, both from a religious and a scientific point of view. 12

11 See Tess Cosslett, Science and Religion in the Nineteenth Century, Cambridge, Cambridge University Press, 1984, pp. 1-45.

12 For the use of the Christian analogical tradition in the Victorian period, see Michael Wheeler, Death and the Future Life In Victorian Literature and Theology, Cambridge, Cambridge University Press, 1990, pp. 12-16. 
'Inferior Animals' similarly mixes serious discussion of animal language and what it might mean, with the playful use of that language as a device to mock evolutionary thought. 'That they do understand each other's song is clear', says the narrator, judiciously. The problem of knowing what they say is mutual unintelligibility: 'we are altogether as ignorant' of their language 'as they would be of ours round a large dinner table'. This idea is then used to mock human pretensions: 'As to the noises, there is not much to choose between them in the manner of agreeableness. Nay, of the two, perhaps the din produced by human voices is the more discordant and confused' (193). The narrator proceeds to lament the 'necessary unlearning' of our childhood instinct for intercommunication with the animals (194). She quotes from Novalis: 'Only children, or child-like men . . . have any chance of breaking through the charm which holds nature thus as it were frozen around us, like a petrified magic city' (196). She then appeals to the (grown-up) reader to join her in becoming a child, and approach the rooks:

Come! own with me how hateful were the lessons which undeceived us from our earlier instincts of faith and sweet companionship with all created things: and let us go forth together, and for a while forget such teaching. Hand in hand, in the dear confiding way in which only children use, let us go forth into the fields, and read the hidden secrets of the world. (196)

This passage could stand as an apologia for all her parables: the childlike frame of mind allows a temporary regression to the primitive and poetic anthropomorphic vision of Nature. Valuing the childish allows the narrator to attack 'the great philosophers', who cannot explain or translate the rooks' behaviour, and so prove themselves inadequate as guides to the Creator's larger purposes and proceedings (197). Preferable is the childlike vision, which works like magic, but also to dispel magic: 'the spell is broken at last, and language, language, resounds on every side!' (198) Then follows a separate section, entitled 'What the Rook Says'. What the rooks turn out to be saying, however, is a very funny parody of evolutionary argument, enjoyable for children, but with an extra meaning for adults. Man's characteristics, as observed by the rooks, are interpreted as a degeneration from his original rook-like form - his arms are vestigial wings, his clothes the remains of feathers. Man, they 
argue, is attempting to become a rook again, as evidenced, for instance by his predilection for black:

'Black also the usual colour of the coverings with which men protect their heads from the outer air. Black even the clumsy boots which cover their feet. Black pretty nearly everything, everywhere, Mr Ravenwing positively declared.

'And on another occasion, in some parts of the country, he came upon whole races of men who left their homes every morning at an early hour, white, but returned to them every evening $\underline{\text { black}}$, having accomplished this transformation during the course of the day.' (208)

The rook-evolutionist is talking about coal-mines here, as soon becomes clear.

All through the rooks' debate, the narrator as observer interjects. She seems to have forgotten her child-like transformation, and makes authoritative comments designed to put the rooks in their place and point the moral: '- But I - the transcriber of this arrant nonsense - am ready, as I listen to their senseless caws, to throw down my tablets in despair. Oh! to think of finding the false glozings of philosophical conceit among the birds of the air' (199); or, later, ' Am I then half-convinced? - Yet for an imperfect being to hope to fathom the higher nature? Bah! what balderdash of folly!' (207). This is a recurring moral in many of Mrs Gatty's parables: that the 'lower' (animals, children, or man in relation to God) do not possess the faculties to understand the 'higher' nature, and must submit to the authority of those wiser and better endowed. While the rooks are being mocked as 'inferior', because they label man as 'inferior', at the same time they are acting as a parody of human scientific behaviour and pretentions; so, in a further twist, the story is also about human 'inferiority'. Some words the narrator used in the opening frame of the story, mocking human language, are now spoken by the rooks: 'There is, in fact, "neither sweetness nor sublimity, neither melody nor majesty, in the shouting, and piping, and whistling, and hissing, and barking of closely intermixed human voices and laughter"'. Hearing them, the narrator becomes quite giddy: ' - Where am I? - where am I? - what am I about? Is some mocking echo repeating my former words?' (211) Her pretention of adult, and human, authority is undercut. She finally extricates herself from the situation by turning it all into a drem. The sympathetic, childlike reader has disappeared, and the 
whole vision was inspired by a certain 'book' that was lying on her desk, perhaps by Darwin, though the arguments used by the rooks are more Lamarkian, depending on the inheritance of acquired characteristics. But, as Ellegard has pointed out, very few of Darwin's readers grasped the subtleties and implications of his argument about Natural Selection. 13

The convolutions of this story are quite daunting. What seems to be happening is that on the one hand a hierarchy of inferior and superior animals, rooks and men, is being asserted, but on the other, man is being debased from his 'superior' status, and a rook's eye view of him is given a degree of truth. At the same time, the child's eye view, which delights in an improbable fable, is given priority over the prideful grownup evolutionists who do not know all the answers, though the adult voice of the narrator is needed to point the moral for us. The carnivalesque propensities of talking animal stories are emerging: the narrator seems all too aware of the need to frame and restrict carnival to a special period of licence, belonging here to the child and to the dream. ${ }^{14}$

This need to clamp down again, and re-assert hierarchy, suggests that none of these stories are giving animals a 'voice' in present-day animal liberationist terms. 15 They are also of a different genre than for instance Anna Sewell's Black Beauty (1896), which aims to promote kindness to animals by telling a life-story in the voice and from the perspective of an animal. This sort of story was particulary associated

\section{Alvar Ellegard, Darwin and the General Reader, Chicago: University of Chicago} Press, 1990.

14 For some interesting ideas on the concept of carnival applied to children's literature, see John Stephens, Language and Ideology in Children's Fiction, London: Longmans, 1992, pp. 120-57.

15 See Linda Vance, 'Beyond Just-So Stories; Narrative, Animals, and Ethics', p. 1823, and Marian Scholtmeijer, 'The Power of Otherness: Animals in Women's Fiction', p. 242, both in Animals and Women: Feminist Theoretical Explorations, ed. Carol J. Adams and Josephine Donovan, Durham, N.C.: Duke University Press, 1995. 
with women's mission to educate and humanise children. ${ }^{16}$ Mrs Gatty's analogous story, 'Kicking', seems at first to put us in the horse's place: everyone 'ought to sit from time to time in his neighbour's chair, and look with his neighbour's eyes, from his neighbour's position, at what he himself is about'. This will make us 'wiser, as well as kinder'. In this story, we are to sit 'in neighbour Firefly the spirited young chestnut colt's chair' - a rather grotesque metaphor, which functions to remind us of the animal/human divide even while recommending we cross it (249). And the moral of the story is once more submission, with no hint of criticism for any of the methods used to 'break' the colt. The only criticism is of an old mare whose grumbling wrongly provokes Firefly into resistance against men. The right advice is given by a wise old Welsh pony - advice directly applicable to children as well, in Mrs Gatty's scheme of analogies: 'they were not brought here to be teazed to death . . . but to prepare them for being taught a thousand nice things which they would never be able to do if they were not taught, and which it would be immensely jolly to do, when the teaching was once over' (257). Kingsley and Kipling also do not use animal voices to argue for the better treatment of animals. Kingsley includes a lesson of kindness, but is is given by the allegorical Mrs Bedonebyasyoudid, not through the voices of animals. In Kipling, the Jungle Book story 'The White Seal' focuses on the cruelty of the seal hunters, but there is no appeal to humans to behave differently. Instead, the seal hero leads his people to safety in a land without men (99-127). In the Mowgli stories, the stupid villagers are cruel to Mowgli and to each other, not to animals.

Both Kingsley and Kipling also exhibit the self-consciousness about animal language that Mrs Gatty shows in 'Inferior Animals'. In The Water Babies, Kingsley asserts that language is a paramount human distinguishing characteristic. He mocks the controversy between Huxley and Owen over the similarity or not of human and ape brains: 'You may think that there are other more important differences between you and an ape, such as being able to speak, and make machines, and know right from

16 See Barbara T. Gates, 'Revisioning Darwin with Sympathy: Arabella Buckley', in Natural Eloquence: Women Reinscribe Science, ed. Barbara T. Gates and Ann B. Shteir, Madison: University of Wisconsin Press, 1997, pp. 164-5. 
wrong, and say your prayers' (111-12). But earlier he has told his child reader, 'Now you must know that all things under the water talk; only not such a language as ours; but such as horses, and dogs, and cows, and birds talk to each other, and Tom soon learnt to understand them and talk to them' (66). This animal language is allowable because it is of a different kind, and because it is understood by a special person, a half-animal, a fish-like boy.

Both these characteristics also apply to the animals' language in Kipling's 'Mowgli' stories. It is again only a special, half-animal boy, Mowgli, who can understand them, though he does not have the fantastic, playful status of Tom the water-baby, but is grounded in real stories of boys brought up by wolves. The animals speak in a special, heightened, archaic form of English, in line with their more primitive and poetic staus: "'Out!" snapped Father Wolf. "Out and hunt with thy master. Thou hast done harm enough for one night." "I go," said Tabaqui quietly. "Ye can hear Shere Khan below in the thickets. I might have saved myself the message"' (I: 3-5) Every now and then the narrator, or 'editor' as he calls himself in the Preface, puts in brackets a translation of what they are saying, either translating individual terms like 'the Gidur Log [the Jackal People]' (I: 2), or whole phrases: 'the stinging fly that comes out of white smoke [Hathi meant the rifle]' (II: 26). Here, the animals invent metaphors for objects made or controlled by man. Fire is called 'the Red Flower'. The editor appears openly as translator in a headnote to one of the interspersed poems: 'Just to give you an idea of the immense variety of the Jungle Law, I have translated into verse (Baloo always recited them in a kind of sing-song) a few of the laws that apply to the wolves' (II: 29). How, then, does the editor know this language? The very tongue-in-cheek Preface claims that the stories come from many animal informants. Many of Kipling's stories depend on a narrator who is in the know of some secret or esoteric society, culture or organisation. Satya P. Mohanty has likened this to an imperialist desire to know and dominate the natives. 17

17 'Drawing the Color Line: Kipling and the Culture of Colonial Rule', in The Bounds of Race: Perspectives on Hegemony and Resistance, ed. Dominick LaCapra, Ithaca: Cornell University Press, 1991. 
In this connection it is significant that there is an ambiguity in the Mowgli stories as to whether knowing animal language means an admission to kinship, or a means to mastery. Mowgli is taught the 'Master Words' of the Jungle, in the speech of different species - the bird-people, the snake-people - so that he will be able to say 'We be of one blood, you and I' in any language. Human and animal are related, but knowing the words is also a kind of trick, by which Mowgli compels the animals to do his will. The stories chart not only Mowgli's painful division between his animal and his human natures - 'I am two Mowglis' he sings - and his inability to be accepted into either community, Jungle or village, but also his gradual rise to dominance in the Jungle, so that he ends up acknowledged 'Master of the Jungle', recognised as such by both Hathi the elephant and Kaa the python, previously the wisest and most powerful. All this is part of his growing up and leaving the childhood space of play and ambivalence between human and animal natures. ${ }^{18}$ On either side of this transition to adulthood are the last of the children's Mowgli stories, 'The Spring Running', and the only 'grown-up' Mowgli story, 'In the Rukh', which do not quite fit together.

In 'The Spring Running', the animals' language has changed, because of the Spring, 'the Time of New Talk', and they no longer pay Mowgli any attention, as 'they were busy hunting and fighting and killing and singing' (II: 291). The unspoken subtext is that this is all to do with mating, and that it is sex, too, that drives Mowgli back to humankind. As Darwin says, 'The sexes of many animals incessantly call for each other during the breeding-season; and in not a few cases the male endeavours thus to excite the female'. 19 This 'new talk' excludes Mowgli, and threatens to upset the ordered hierarchy of the Jungle and its language. Mowgli rebukes Bagheera, the panther, for his childish behaviour, "'is it well for the Black Panther so to mouth and

18 John McBratney sees this safe space also as a place where the boundaries of racial and colonial identities can be crossed. See 'Imperial Subjects, Imperial Space', Victorian Studies 35: 3 (Spring 1992): 277-93.

19 The Expression of the Emotions in Man and Animals, London: John Murray, 1904, p. 85. 
cough, and howl and roll? Remember, we be the Masters of the Jungle, thou and I."' Bagheera answers,

'Indeed, yes; I hear, Man-cub . . . We be surely the Masters of the Jungle! Who is so strong as Mowgli? Who so wise?' There was a curious drawl in the voice that made Mowgli turn to see whether by any chance the Black Panther were making fun of him, for the Jungle is full of words that sound like one thing, but mean another. 'I said we be beyond question Masters of the Jungle,' Bagheera repeated. 'Have I done wrong? I did not know that the Man-cub no longer lay upon the ground. Does he fly, then?' (265-6)

Bagheera's irony, and the notion, first introduced here in the last Mowgli story, that the Jungle language could have double meanings, undercut Mowgli's pretentions to be Master. Similarly, In Mrs Gatty's 'Inferior Animals', the rooks' language has doublemeanings, that both demonstrate man's 'mastery' and the birds' 'inferiority', and overturn man's dominance by mocking his pretentions. Once animals have been allowed language of any complexity, irony can creep in, and upset fixed animal/human hierarchies. The child, who is identified with the animals and their speech, participates in these inversions. 'Child', as we have seen, is a pivotal term in the relationship of man and animals: the link to the 'primitive' and 'poetic' world of talking animals, and the 'primitive' who must be civlised in order to become an adult. I am suggesting that 'The Spring Running' and 'In the Rukh', as 'growing-up' stories, enact these ambiguities. In 'The Spring Running', the sexuality that unbalances Mowgli's relation of dominance to the animals, and sends him out to humankind, is paradoxically seen as 'childish' behaviour on the animals' part, their very 'animality'. Sexuality is Mowgli's unruly animal nature that he cannot fully master. In the grown-up story, 'In the Rukh', however, sex and then marriage act to integrate Mowgli safely into human organisations, as he takes a job, with a pension, as a ranger under Gisbourne Sahib of the Department of Woods and Forests. This story was in fact written before the other Mowgli stories, and is referred to at the end of 'Tiger! Tiger!', the third Mowgli story in the first Jungle Book, which ends when Mowgli has been cast out by both Man Pack and Wolf Pack: 'So Mowgli went away and hunted with the four wolf cubs in the Jungle from that day on. But he was not always alone, because years afterwards he 
became a man and married. But that is a story for grown-ups' (I: 95). The most notable difference from the stories for children is that the animals do not talk. Mowgli speaking animal language is observed from outside, from an adult human point of view: 'He put out his hand to sign for silence, and still lying on his back called aloud thrice - with a deep gurgling cry that was new to Gisbourne'. ${ }^{20}$ The narrator/translator, who could speak to animals because he was speaking to children, has disappeared.

Mowgli' s equality with the animals is also not evident: his four wolf-brothers appear here more like performing dogs. Mowgli is seen 'playing upon a rude bamboo flute, to whose music four huge wolves danced solemnly on their hind legs'. ${ }^{21}$ In 'Tiger! Tiger!', a Jungle Book story, when the native hunter is mocked for his false tales about Mowgli, 'Buldeo embroidered the story of his adventures in the Jungle, till he ended by saying that Akela stood up on his hind legs and talked like a man' (I: 93). Paradoxically, of course, the animals do talk like man, though it is always emphasised that it is a different kind of language. In the Second Jungle Book, as the animals encircle Buldeo, they talk unconcernedly, 'for their speech began below the lowest end of the scale that untrained human beings can hear' (II: 68). The sort of 'gurgle' that Gisbourne hears is not evident: animal language is a silent secret; and of course there is no question in the Jungle Books of the animals 'standing on their hind legs'. The animals are diminished in this grown-up story, and while Mowgli is seen as a 'wood god', a 'Faunus', he is also reduced to a government employee. He is 'placed' in history and literature: '"he is an anachronism, for he is before der Iron Age, and der Stone Age. Look here, he is at der beginnings of der history of man"', says Muller, the head of the Department of Woods and Forests. '"He's like the illustrations in the Classical Dictionary"', thinks Gisbourne. Mowgli appears 'in the very form and likeness of that Greek god who is so lavishly described in the novels'. ${ }^{22}$ This very literary classicism is quite different from Buldeo's superstitious beliefs, or at least trying to appear so.

20 'In the Rukh', p. 205

21 ibid. p. 218.

22 ibid. pp. 216, 198, 215. 
Much Victorian debate on 'Man's' place in nature centred on the notion of the 'missing link'. For the most part, representations of or allusions to this figure in adult literature are monstrous and terrifying: the hairy animalistic Mr Hyde (1886); the tormented half animal, half human creatures in Wells's Island of Dr Moreau; the atavistic Caliban in Browning's 'Caliban upon Setebos' (1864). All these figures provide comment on existing human nature, and its repulsive 'animal' component. In the domain of children's literature, however, such hybrids can appear charming and enjoyable: the wolf-boy Mowgli, the water-baby Tom, and the talking animals themselves. Somehow, the grown-up Mowgli of 'In the Rukh' also retains his charm partly with the help from the Classical Dictionary, partly by his unambiguous human dominance over the animals: he isn't half animal. The child Mowgli, however, often seems so, and is not monstrous.

The 'missing link' also appears in another way in the Jungle Books, in the characters of the monkeys, the Bandar-log, and their relation to language. Unlike the other animals, they have no language of their own, and no law or leader. On one level, their community is a satire on America: 'What the Bandar-log think now the Jungle will think later', they claim (I: 39). They are also used to mock the superstitious Indian villagers: while Buldeo tells his stories, 'the monkeys sat and talked in the upper branches' above him and his listeners (I: 76). But their status as almost-human is also in question: the monkeys are outcast, they are 'dirt', calling up notions of taboo and the abject. 23 They are so disgusting because they are not human and not animal they are what these categories define themselves against. The animals Mowgli defines himself with are powerful carnivores: wolves, bears, panthers, pythons. ${ }^{24}$ So while

23 For an interesting discussion of taboo and the abject in relation to The Water Babies, and the ideas of Kristeva and Mary Douglas, see Valentine Cunningham, 'Soiled Fairy: The Water Babies in Its Time', Essays in Criticism, 35: 2 (April 1985): $121-48$.

24 This identification also has masculine connotations. As Karen Davis argues, 'Animals summoning forth images of things that are "natural, wild, and free" accord with the "masculine" spirit of adventure and conquest idolised by our culture' 
the stories deal with the ambivalence of Mowgli's animal and human natures, the outcasting of the monkeys preserves a barrier across the obvious evolutionary connection between man and apes. The lawless, parodic behaviour of the monkeys, who steal animal speech and mimic human actions, is of course extremely carnivalesque. Their defeat and punishment places a limit on the free-play, the inversion of hierarchy, that is allowed in Kipling's use of the talking animal convention. On the other hand, because the monkeys are also used as a parody of certain human societies, like Mrs Gatty's rooks, the analogue between monkeys and men creeps back in.

These sorts of rich and complex ambiguities flourish especially in children's stories, where different forms of the talking animal genre exist together - parody, moral tale, nature study - and where messages of growing up and leaving the 'animal' behind clash with messages about the value of the child's primitivism and closeness to Nature. In these stories, scientific and evolutionary ideas about the relation of man and animals are presented, attacked, played with, parodied, without either the terrifying monstrosity of The Island of Dr Moreau, or the bland classicism of 'In the Rukh'. Writing for children provides a space of license and play, though, paradoxically, one which must also be watched over and controlled by the adult narrator, as the necessary transgressions of the talking animal convention, and the ambiguous valuation of the 'child' always threaten to escape from control.

('Thinking like a Chicken: Farm Animals and the Feminine Connection', in Adams and Donovan, p. 196). However, Kingsley has no problems in associating his male hero with weak and powerless water creatures. Perhaps Kipling is part of the forging of a a new, imperial masculinity. 